\title{
Human serum-derived hydroxy long-chain fatty acids exhibit anti-inflammatory and anti-proliferative activity
}

\author{
Shawn A Ritchie ${ }^{1 *}$, Dushmanthi Jayasinghe ${ }^{1}$, Gerald F Davies ${ }^{1,2}$, Pearson Ahiahonu', Hong Ma ${ }^{1}$ and \\ Dayan B Goodenowe
}

\begin{abstract}
Background: Circulating levels of novel long-chain hydroxy fatty acids (called GTAs) were recently discovered in the serum of healthy subjects which were shown to be reduced in subjects with colorectal cancer (CRC), independent of tumor burden or disease stage. The levels of GTAs were subsequently observed to exhibit an inverse association with age in the general population. The current work investigates the biological activity of these fatty acids by evaluating the effects of enriched human serum extracts on cell growth and inflammation.

Methods: GTAs were extracted from commercially available bulk human serum and then chromatographically separated into enriched (GTA-positive) and depleted (GTA-negative) fractions. SW620, MCF7 and LPS stimulated RAW264.7 cells were treated with various concentrations of the GTA-positive and GTA-negative extracts, and the effects on cell growth and inflammation determined.

Results: Enriched fractions resulted in poly-ADP ribose polymerase (PARP) cleavage, suppression of NF $\kappa$ B, induction of $\mid \kappa B \alpha$, and reduction in NOS2 mRNA transcript levels. In RAW264.7 mouse macrophage cells, incubation with enriched fractions prior to treatment with LPS blocked the induction of several pro-inflammatory markers including nitric oxide, TNF $\alpha, I L-1 \beta$, NOS2 and COX2.

Conclusions: Our results show that human serum extracts enriched with endogenous long-chain hydroxy fatty acids possess anti-inflammatory and anti-proliferative activity. These findings support a hypothesis that the reduction of these metabolites with age may result in a compromised ability to defend against uncontrolled cell growth and inflammation, and could therefore represent a significant risk for the development of CRC.
\end{abstract}

Keywords: Long-chain fatty acid colorectal cancer, aging, screening, inflammation, NFkB

\section{Background}

Fatty acid metabolism is intricately linked to the regulation of inflammatory processes, which underlie numerous diseases including cancer. For example, arachidonic, decosahexanoic and eicosapentanoic acids (AA, DHA and EPA) can be metabolized into both pro-inflammatory prostaglandins and leukotrienes, as well as into inflammation-resolving lipoxins, protectins and resolvins [1-3]. The failure to resolve acute inflammation through a lack of conversion to these latter products can result in a chronic inflammatory state, which over time can

\footnotetext{
* Correspondence: s.ritchie@phenomenome.com

'Phenomenome Discoveries, Inc. Saskatoon, Saskatchewan, Canada

Full list of author information is available at the end of the article
}

drive the development of inflammation-associated conditions including cancer, neurodegeneration, and others [4-10]. Functionally, many of these lipids have been shown to mediate their inflammation-associated effects through pathways involving the transcription factor $\mathrm{NF} \kappa \mathrm{B}$ and subsequent downstream pro-inflammatory molecules such as TNF $\alpha, \mathrm{IL}-1 \beta, \mathrm{COX} 2$, and NOS2, for example [11-16].

Recently we reported on a novel class of hydroxylated long-chain fatty acids (called GTAs for gastrointestinal tract acids) present in the serum of healthy subjects and significantly reduced from the serum of colorectal cancer (CRC) patients $[17,18]$. Structurally, the molecules resemble very long chain ( 28 carbon) mimetics of the resolvins 
and protectins, containing multiple double bonds and at least two hydroxyl groups. The levels of GTAs do not change following treatment and show no correlation with tumor stage, suggesting that the reduction is not caused by the presence of the disease $[17,18]$. An inverse association between GTAs and age in the average-risk population further suggests that the reduction exists prior to cancer development, and may therefore represent a causal factor for the establishment and/or progression of the disease [18]. However, little is currently known about the biochemical role these molecules play in the disease process. The work reported herein, therefore, was carried out to investigate the effects of GTAs in vitro through the treatment of various cell lines with semi-purified GTAenriched human serum extracts.

\section{Methods}

\section{Cell lines and tissue culture}

SW620, MCF-7 and RAW264.7 were purchased from ATCC and cultured in high glucose DMEM, 10\% FBS at $37^{\circ} \mathrm{C}, 5 \% \mathrm{CO}_{2}$. Cells were seeded at $1 \times 10^{6} /$ well in $6-$ well plates 24 hours prior to treatment with varying concentrations of GTA+ve extract, GTA-ve extract or vehicle (DMSO). RAW264.7 cells were pretreated with the extracts for 4 hours followed by the addition of LPS at $1 \mathrm{ug} / \mathrm{ml}$ (cat. No. L4391, Sigma) for 20 hours. Cells were harvested using a 2:1 ratio of Versene and TryPLe express (Gibco). The cell pellet was washed twice with phosphate buffered saline (PBS) and the stored at $-80^{\circ} \mathrm{C}$ until extracted. Cell photographs were taken at $200 \times$ magnification on a phase-contrast EVOS digital microscope. All experiments were performed at least three times in duplicate or triplicate wells.

\section{Serum extraction, chromatography and mass spectrometry}

Commercially available lyopholized human serum (Randox Laboratories, Canada) was resolubilized in double de-ionized water. The serum was extracted with 1:5 ratio of $1 \%$ ammonium hydroxide:ethyl acetate (Commercial grade, VWR) as previously described [17]. Ethyl acetate extracts were evaporated to dryness under reduced pressure $\left(37^{\circ} \mathrm{C} / 100 \mathrm{rpm}\right)$ and re-suspended in methanol. Reverse phase silica (15 - 20 mg; WP C18 silica, $45 \mu \mathrm{m}, 275 \AA$ ) was added into the serum methanol extract and evaporated to complete dryness under reduced pressure $\left(45^{\circ} \mathrm{C} / 150 \mathrm{rpm}\right)$, which was then subjected to reverse phase flash column chromatography (FCC) with a step gradient elution; acetonitrile - water $25: 75$ to $100 \%$ acetonitrile. Eluent was fractionated into 12 aliquots (F1 - F12), which were each analysed for GTA content using HPLC-coupled tandem mass spectrometry on an ABI QSTAR XL mass spectrometer as previously described [17].

\section{Proliferation assays}

Cell proliferation was determined using the MTT assay (3-(4,5-dimethylthiazol-2-yl)-2,5-diphenyltetrazolium bromide). Cell suspensions were prepared at a concentration of approximately $10^{5}$ cells per $\mathrm{ml}$ as determined by standard hemocytometry, and cultured in 6-well multi-well plates. Prior to MTT analysis, cells were subcultured in phenol red-free DMEM medium to avoid interference with the colorimetric analysis of the purple formazan MTT product. Following treatment with serum extracts, cells were treated with MTT followed by washing with PBS, DMSO solubilization of the formazan product, and subjected to spectrophotometric analysis at $570 \mathrm{~nm}$.

\section{Protein analysis}

Cell pellets were resuspended in ice-cold lysis buffer (20 $\mathrm{mM}$ Tris (pH 7.5), $150 \mathrm{mM} \mathrm{NaCl}, 0.5 \mathrm{mM}$ EDTA, 0.1 mM EGTA, $0.1 \%$ NP-40 plus $1 \mathrm{X}$ mammalian cell antiprotease cocktail (Sigma)). The cells were lysed using multiple freeze-thaw cycles followed by pulse sonication on ice and centrifugation at $3000 \mathrm{rpm}$ for 5 minutes at $4^{\circ} \mathrm{C}$ to remove cell debris. Western blot analysis of these protein lysates was performed as previously described [19]. Briefly, equivalent amounts of protein were assessed by Bradford protein assay using BioRad Protein Reagent and resolved by $10 \%$ sodium dodecyl sulfate-polyacrylamide gel electrophoresis (SDS-PAGE). Following electrophoresis the proteins were trans-blotted onto nitrocellulose membranes (Pall-VWR). The membranes were blocked overnight at $4{ }^{\circ} \mathrm{C}$ on a gyratory plate with $5 \%$ molecular grade skim milk powder (BioRad Laboratories) in phosphate-buffered saline (PBS) containing 0.1\% Tween-20 (PBST). Primary and secondary antibody incubations and subsequent washes were carried out in the same buffer. Primary antibodies were obtained from Santa Cruz Biotechnology. The primary antibody for GAPDH was purchased from Sigma. Secondary HRP antibodies were purchased from BioRad. Blots were immunoprobed overnight with primary antibodies at a 1:1000 dilution. Secondary HRP antibody was applied at room temperature on a gyratory plate at a concentration of 1:10,000 for 30 min. Following multiple washes, an enhanced chemiluminescence detection system (Dupont-NEN) was used to detect the target antigen/antibody complexes. Blots were then stripped at $50^{\circ} \mathrm{C}$ for 30 minutes in a Tris-buffered 20\% SDS/1\% 2-mercaptoethanol stripping solution, washed and re-probed with GAPDH antibody (Sigma) to verify protein loading equivalency. For ELISA analysis, raw cells were treated as described above and conditioned medium or cell lysates were used to determine concentrations of TNF $\alpha$ (Cat. No. KMC3011, Invitrogen), and IL$1 \beta$ (Cat. No. MLB00B, Quantikine), according to the manufacturer's instructions. 


\section{Nitric oxide assay}

Nitrite concentration in conditioned media was measured by Griess Reagent (Cat. No. G2930, Promega) according to the manufacturer's instructions.

\section{Quantitative Real-Time PCR}

Total RNA was isolated from cell pellets using Trizol (Cat. No.15596-018, Invitrogen) as per manufacturer's instruction. RNA was resuspended in $50 \mu \mathrm{L}$ of DEPC treated water and stored at $-80^{\circ} \mathrm{C}$. RNA concentration and purity was determined by spectrophotometry at 260 and $280 \mathrm{~nm}$. Reverse transcription was performed using qScript cDNA super mix (Cat No. 95048-100, Quanta Biosciences). PCR was conducted by using Fast SYBR Green Master Mix (Cat No. 4385612, AB Applied Biosystems) on an Applied Biosystems Step One Plus Realtime PCR system. The relative number of each transcript copy was normalized by house-keeping gene Beta Actin. Real-time PCR primers used were as follows: NOS2 forward, CACCTTGGAGTTCACCCAGT; NOS2 reverse, ACCACTCGTACTTGGGATGC; COX2 forward, CCCCCACAGTCAAAGACACT; COX2 reverse, CTCATCACCCCACTCAGGAT; TNF $\alpha$ forward, AG AAGTTCCCAAATGGCCTC; TNFa reverse, GTC TTTGAGATCCATGCCGT; IL-1 $\beta$ forward, TGTGA AATGCCACCTTTTGA; IL-1 $\beta$ reverse, TGAGTG ATACTGCCTGCCTG.

\section{Clinical Samples}

Serum from a previously reported CRC patient and control population originating from Chiba University was equally pooled [17]. Ethyl-acetate extracts of the pooled control and CRC serum were subject to HPLC-coupled tandem mass spectrometry to determine relative GTA levels as previously described [17].

\section{Statistical Methods}

Where data is averaged, error bars represent 1 standard deviation (S.D.) of the mean. Significance was determined if $\mathrm{p}<0.05$ using unpaired Student's $\mathrm{T}$ test (Microsoft Excel).

\section{Results}

\section{Treatment of cells with un-enriched human serum} extracts

We first determined whether crude serum ethyl acetate extract, prior to chromatographic enrichment of GTAs, would have any effect on cellular growth by treating cells with commercially available bulk human serum extracts (see methods). The total ion chromatogram (TIC) of the organic fraction following HPLC-coupled time-of-flight (TOF) mass spectrometry is shown in Figure 1A. The extracted mass spectra of the complete TIC is shown in Figure 1B, which was dominated by various free fatty acids but contained detectable levels of GTAs including those with masses of 446 (C28H46O4), 448 $(\mathrm{C} 28 \mathrm{H} 48 \mathrm{O} 4)$ and $450(\mathrm{C} 28 \mathrm{H} 50 \mathrm{O} 4) \mathrm{Da}$ (Figures $1 \mathrm{~B}$ and $1 \mathrm{C})$. By calculating the peak areas of the three chromatograms, we estimated that these three GTAs represented no more than $0.15 \%$ of the total ion current in the sample. Incubation of SW620 cells with up to 80 $\mathrm{ug} / \mathrm{ml}$ of the extract for 48 hours showed no effect on cell proliferation (Figure 1D) or any effects on cell morphology as assessed by light microscopy (not shown).

Organic serum extract was next subjected to flash column chromatography as described in the methods, resulting in 12 fractions which were subsequently analyzed by HPLC-MS to determine GTA content. Although other components were present in all the fractions, only fraction 9 out of the 12 was enriched for the C28 GTAs (referred to as the GTA+ve fraction). A GTA negative control fraction (fraction 8, lacking any detectable GTAs) was also selected for the studies described below. Representative total ion chromatograms, extracted mass spectra and selected ion chromatograms of the three C28 GTAs for the GTA-ve and GTA+ve fractions are shown in Figures $2 \mathrm{~A}$ and $2 \mathrm{~B}$, respectively. By comparing the sums of the selected ion chromatograms of the three GTAs to the total ion currents, we estimated that the GTA+ve fraction contained approximately $21 \%$ C28 GTAs while the GTA-ve fraction had no detectable levels (bottom panel of Figures $2 \mathrm{~A}$ and $2 \mathrm{~B}$ ). The non-GTA background components for both fractions were similar, and the most abundant non-GTA components in the GTA+ve fraction were also the most abundant components in the GTA-ve fraction. Therefore, the two fractions were compositionally similar other than the $21 \%$ GTA content of the GTA+ve fraction, which represented an approximately 143-fold enrichment of the three C28 GTA metabolites over the crude organic serum extract (as shown in Figure $1 \mathrm{~A})$. These fractionations were repeated several times with consistent results. We therefore concluded that the fractions were sufficiently matched for investigating biological activity as described below. For comparison, the relative levels of the three C28 GTAs from 40 pooled CRC patients' serum and serum from 40 matched control subjects is shown in Figure 2C.

\section{GTA+ve human serum extracts inhibit cell proliferation and induce PARP fragmentation}

We determined whether the enriched GTA+ve fraction had any effects on cell viability compared to the GTAve fraction by treating SW620 cells for $24 \mathrm{hrs}$ with three concentrations of each fraction and measuring the effect on cell proliferation by MTT assay. The GTA+ve fraction showed a $40 \%$ reduction in cell viability at a dose of $80 \mathrm{ug} / \mathrm{ml}$ (Figure 3A) while GTA-ve treatment had 
A

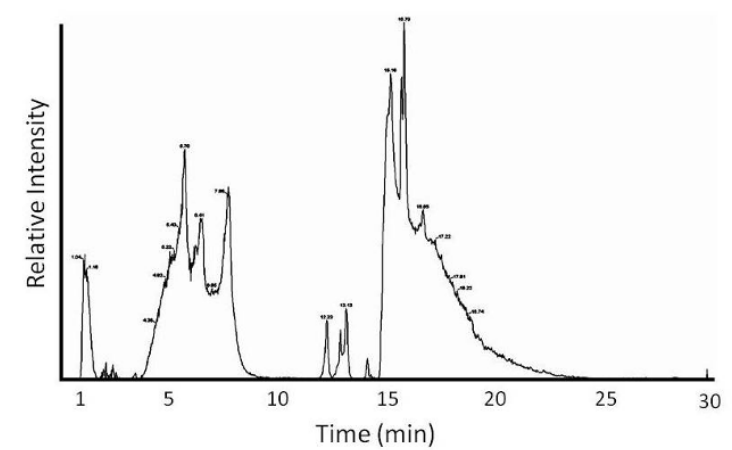

C

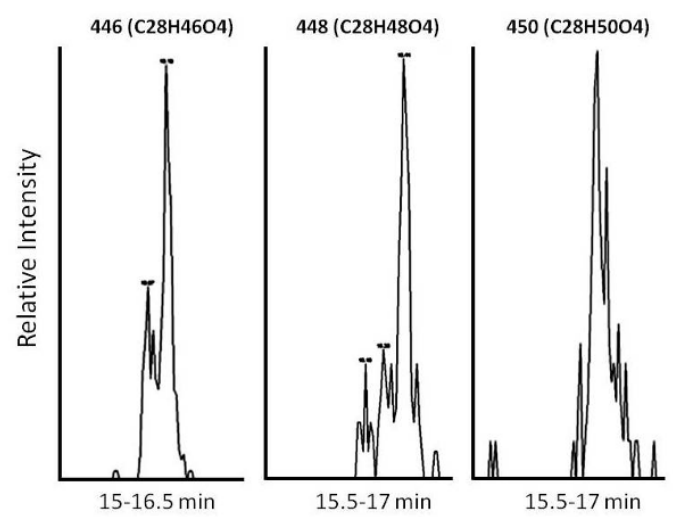

B

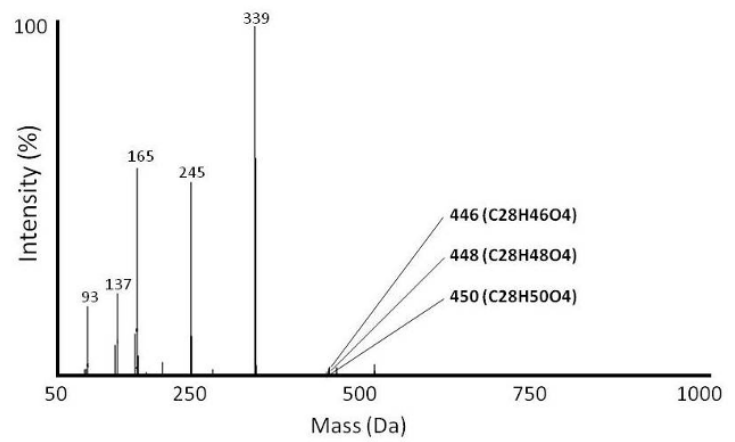

D

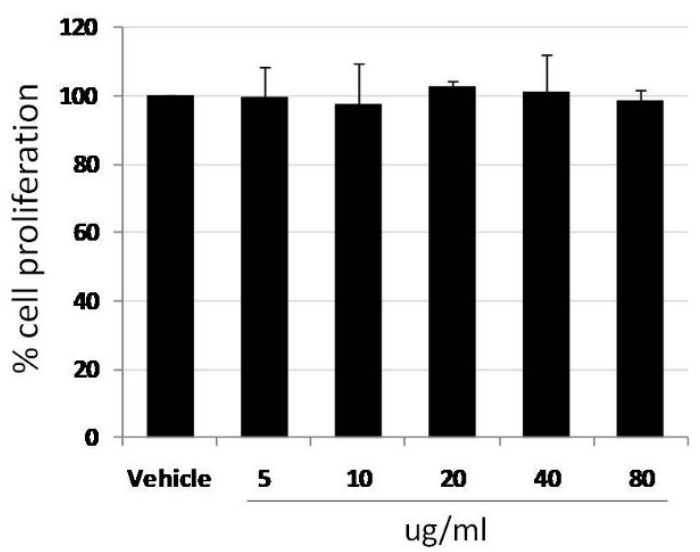

Figure 1 Total ion chromatogram of crude serum organic extract. (A) Total ion current of bulk serum following liquid/liquid extraction and HPLC-coupled mass spectrometry as explained in the methods. (B) Extracted mass spectra of all masses from (A). (C) Extracted ion chromatograms of GTAs 446, 448 and 450 from the total ion current shown in A. (D) Cell proliferation, as assayed by MTT, for SW620 cells treated with up to $80 \mathrm{ug} / \mathrm{ml}$ of the crude serum extract.

no effect. Treatment up to $48 \mathrm{hrs}$ using $80 \mathrm{ug} / \mathrm{ml}$ showed the same $40 \%$ reduction as early as $12 \mathrm{hrs}$, which dropped further to $70 \%$ by 48 hrs (Figure 3B). No effect on cell proliferation was observed with the GTAve fraction or vehicle (DMSO). Evidence of apoptotic activity was determined by the detection of poly(ADPribose) polymerase (PARP) cleavage products through Western blot (Figure 3C). A number of PARP cleavage products including the hallmark 89 and $24 \mathrm{kDa}$ fragments, as well as others (Figure $3 \mathrm{C}$ ), were induced following 48 hrs treatment with GTA+ve fraction, but not with GTA-ve treatment, suggesting a possible pro-apoptotic function of GTAs.

We repeated the studies in MCF7 cells, which upon treatment with GTA+ve fraction showed gross cellular changes visible through phase-contrast microscopy including the appearance of apoptosomes and enlarged nuclei that were not observed with vehicle or GTA-ve treatments (Figures 4A, B and 4C). GTA+ve treatment in MCF-7 cells also resulted in the exclusive induction of the $24 \mathrm{kDa}$ PARP cleavage product relative to vehicle or GTA-ve treatment (Figure 4D), further suggesting a pro-apoptotic activity of GTA-containing extracts.

\section{GTA+ve extracts inhibit pro-inflammatory markers}

The structural resemblance of GTAs to the inflammation-resolving protectins and resolvins prompted us to investigate the effect of GTA+ve extract on pro-inflammatory markers. Treatment of SW620 cells for 24 hours resulted in a profound inhibition of $\mathrm{NF} \kappa \mathrm{B}$ protein level with as little as $20 \mathrm{ug} / \mathrm{ml}$ GTA+ve extract, accompanied by an equally profound induction of $\mathrm{I} \kappa \mathrm{B} \alpha$, neither of which was observed with GTA-ve extract (Figure 5). Protein levels of nitric oxide synthase (NOS2) were also inhibited in cells treated with the GTA+ve fraction (particularly 20 and $40 \mathrm{ug} / \mathrm{ml}$ ), but not in cells treated with the GTA-ve fraction (Figure 5). 


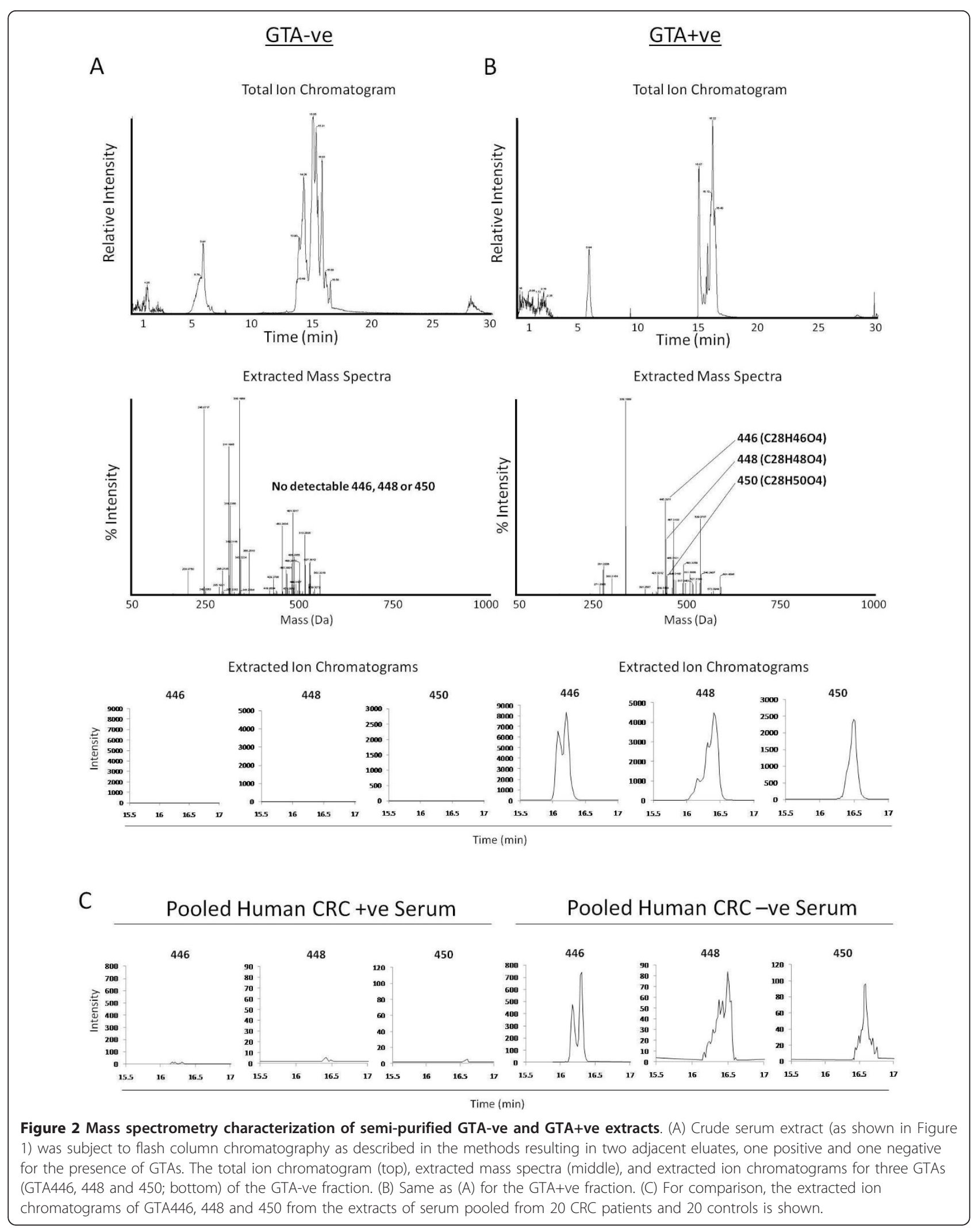




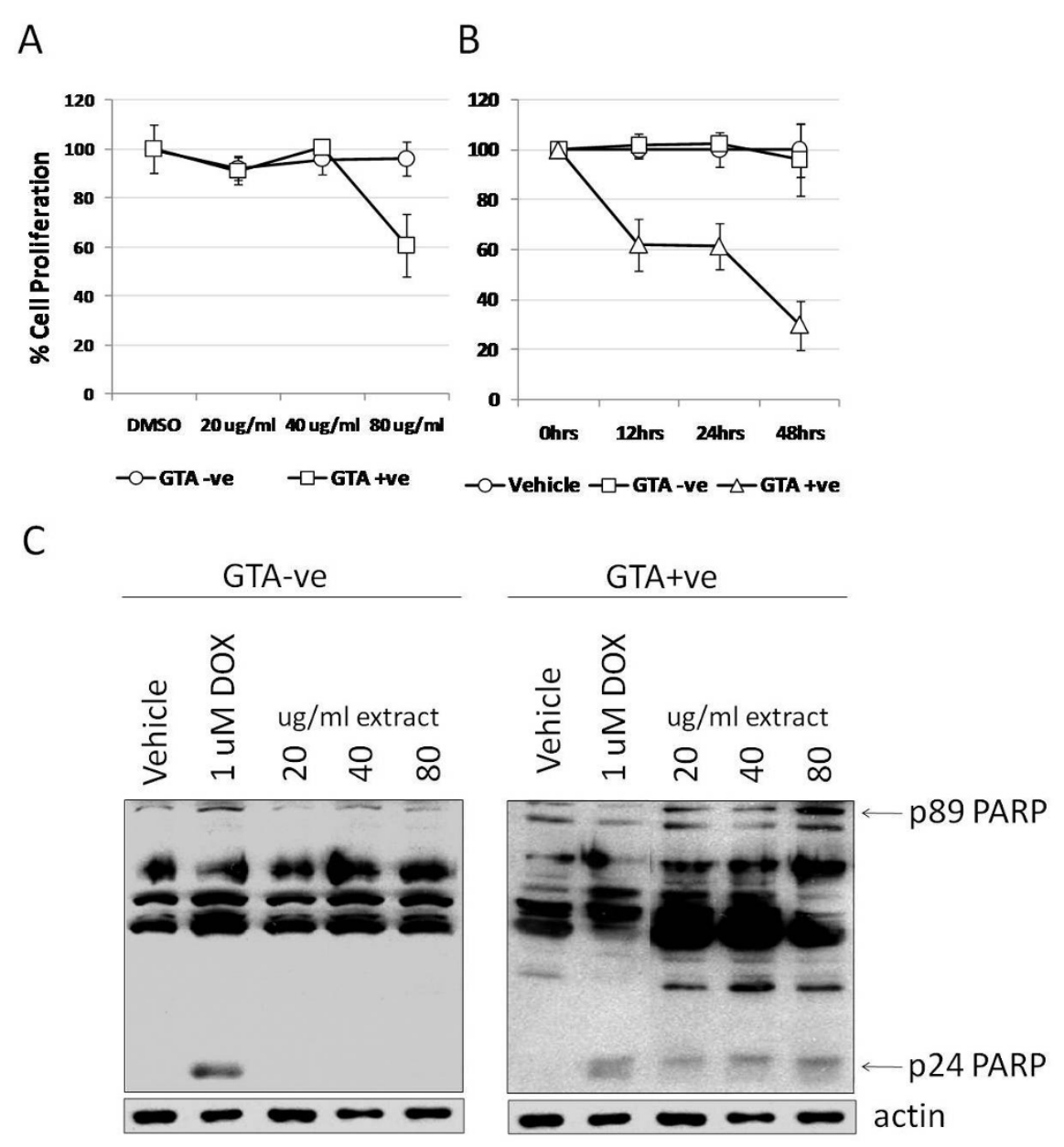

Figure 3 Proliferation of SW620 cells treated with GTA+ve and GTA-ve extracts. (A) SW620 cells were incubated with increasing concentrations of GTA+ve and GTA-ve extracts for 24 hours and proliferation assayed by MTT. (B) The $80 \mathrm{ug} / \mathrm{ml}$ concentration of GTA+ve and GTA-ve extracts was then used to treat cells for up to 48 hours and the effect on cell proliferation assayed by MTT. Data are expressed as percent of vehicle or 0 hrs \pm 1S.D. (C) Representative Western blot analysis of caspase-mediated PARP cleavage fragments resulting from treatment with GTA+ve and -ve extracts. Experiments were repeated at least three times.

To explore further the effect of GTAs on modulating inflammation, we employed the RAW264.7 mouse macrophage line in which a pro-inflammatory state can be induced by treatment with lipopolysaccharide (LPS). RAW264.7 cells were treated for 4 hours with GTA+ve and GTA-ve fractions prior to the addition of LPS, and the effects on various proinflammatory markers evaluated. We observed no affect on RAW264.7 cell growth or proliferation rates during the 20 hours post-GTA treatment. RAW264.7 cells treated with GTA+ve fractions prior to LPS stimulation showed a significant dose-dependent reduction $(\mathrm{p}<0.05)$ in the generation of nitric oxide as assessed through the production of nitrite using the Griess reagent system (Figure 6A), which was mirrored by low levels of NOS2 mRNA transcripts (Figure 6B) and protein levels (Figure 6 C). For comparison (and as controls), cells were also treated with various combinations of free fatty acids including EPA, DHA and equimolar mixtures of 18:1, 18:2 and 18:3 (FA mix), of which only $100 \mathrm{uM}$ DHA showed any protective effect on NOS2 protein induction (Figure 6C).

Similar effects were observed with TNF $\alpha$ upon treatment with GTA+ve extract, which showed significantly reduced mRNA transcript levels $(\mathrm{p}<0.05$, Figure $7 \mathrm{~A})$ as well as protein levels in cell lysates and conditioned media (Figures 7B and 7C, respectively). Consistent with the above findings, transcript levels of COX2 and IL- $1 \beta$ (Figures $8 \mathrm{~A}$ and $8 \mathrm{~B}$ ), as well as IL- $1 \beta$ protein levels (Figure $8 C)$, were also significantly reduced $(p<0.05)$ with GTA+ve treatment. The results indicate that human blood extracts containing GTAs have anti-proliferative and anti-inflammatory properties that GTA-ve extracts lack. 


\section{A}

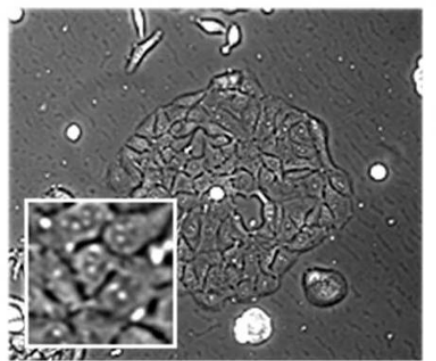

Vehicle
B

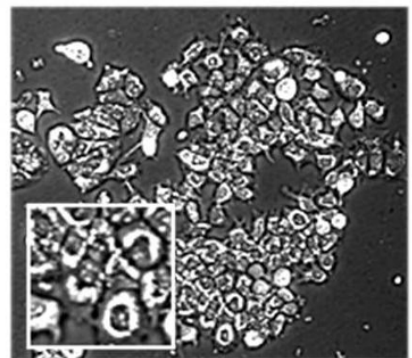

C

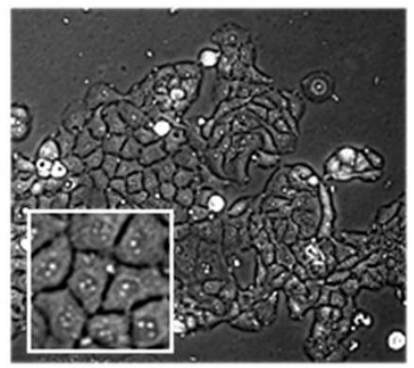

GTA-ve

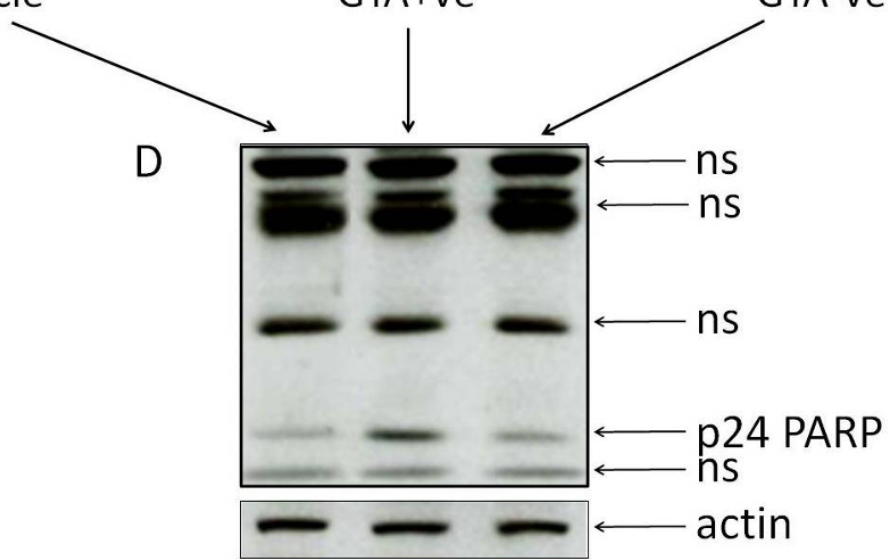

Figure 4 Treatment of MCF7 cells with GTA+ve and GTA-ve extracts. MCF7 cells were incubated with vehicle (A), $80 \mathrm{ug} / \mathrm{ml}$ GTA+ve extract (B), and $80 \mathrm{ug} / \mathrm{ml}$ GTA-ve extract (C) and cells photographed using phase-contrast light microscopy (200x). (D) Western analysis of PARP cleavage products; ns, non-specific.

\section{Discussion}

The regulation of inflammation and the ability to control cell growth are two processes intricately linked with cancer. When acute inflammatory processes are not resolved by the appropriate enzymatic conversion of fatty acid mediators into specific oxygenated products $[1,20,21]$, a state of chronic inflammation can ensue, which can further lead to sporadic DNA mutations, the activation of pro-oncogenic pathways and ultimately cancer (for example see [22]). When such detriments occur, they normally trigger a cascade of intracellular events leading to the induction of apoptotic-mediated cell death. Thus it is the fine control between inflammatory and apoptotic processes, likely early in life, which might be a key determinant of one's risk of subsequent cancer development.

Based on the tumor-independent reduction of GTAs previously reported in CRC patient serum [17], their age-related reduction in the general population [18], and their structural resemblance to the inflammation-resolving protectins and resolvins, we hypothesized that GTAs might represent a novel endogenous cancer-protective metabolic system. Although we focused

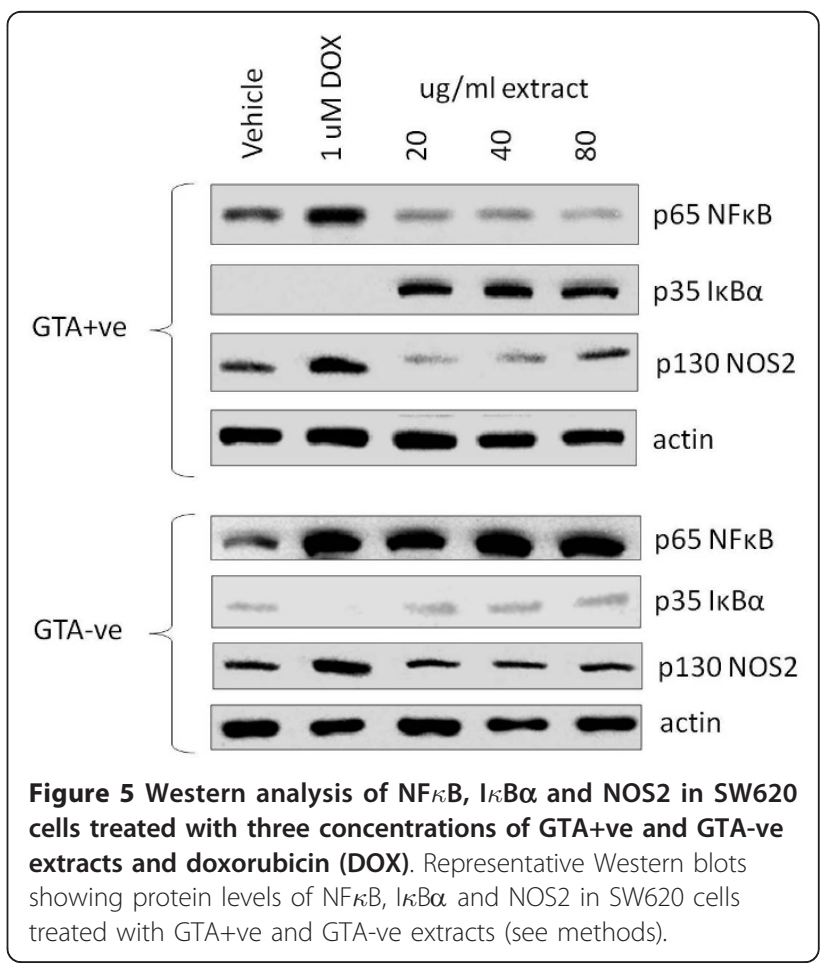




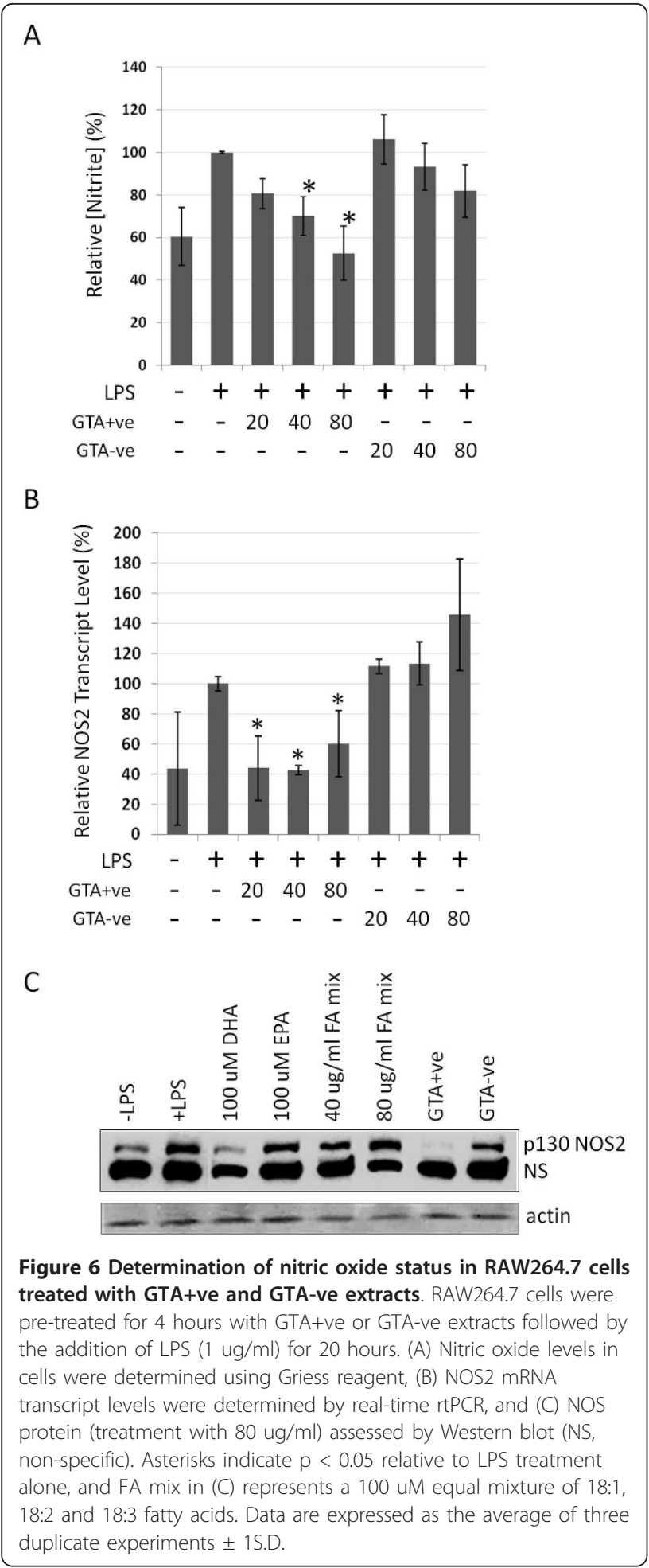

specifically on a subset of 28-carbon GTAs, the GTA family comprises a large number of structurally related novel hydroxylated polyunsaturated ultra long-chain fatty acids ranging in size between 446 and $596 \mathrm{Da}$ and containing up to 36 carbons [17].
A

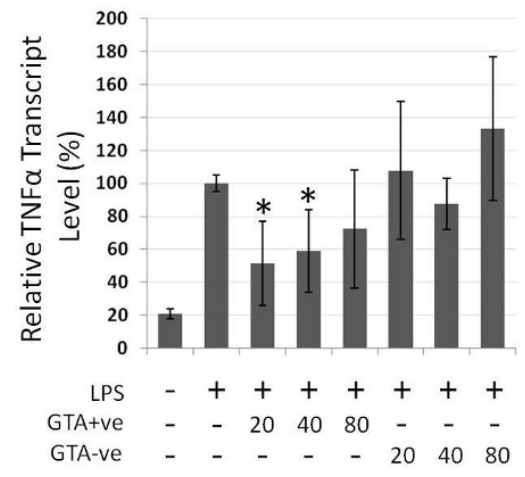

B

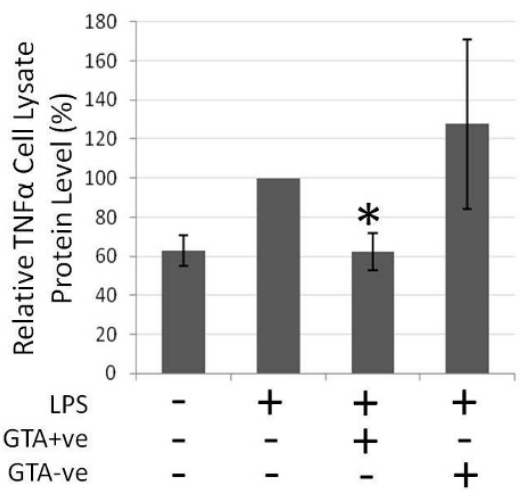

C

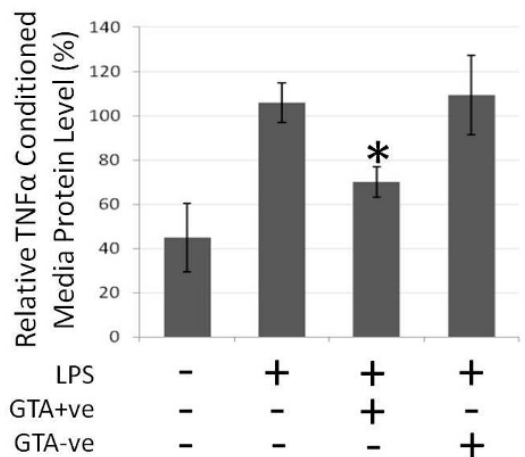

Figure 7 TNF $\alpha$ response in RAW264.7 cells treated with GTA +ve and GTA-ve extracts. RAW264.7 cells were pre-treated for 4 hours with GTA+ve or GTA-ve extracts followed by the addition of LPS ( $1 \mathrm{ug} / \mathrm{ml})$ for 20 hours. (A) TNF $\alpha$ mRNA transcripts as determined by real-time rtPCR, (B) TNF $\alpha$ relative protein levels in cell lysates following $80 \mathrm{ug} / \mathrm{ml}$ treatment, and (C) TNF $\alpha$ protein levels in conditioned media as determined by ELISA. Asterisks indicate $p<0.05$ relative to LPS treatment alone. Data are expressed as the average of three duplicate experiments \pm 1S.D.

In studies completed to date, GTAs appear to represent a human-specific metabolic system as they have only been detected in human serum (or plasma) and not in the serum or plasma of other mammals including mice, rats, cows, dogs, and rabbits. Likewise, GTAs are 
A

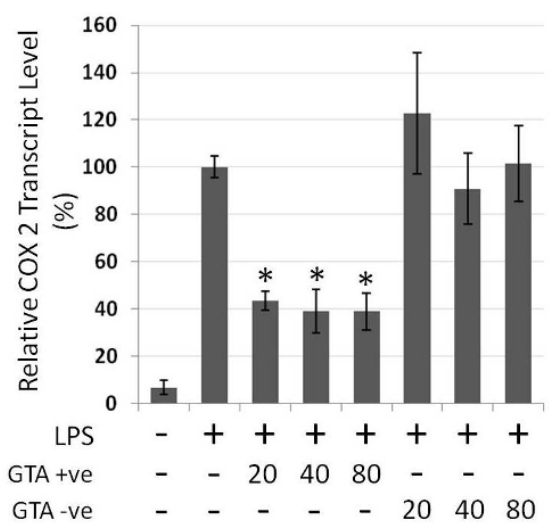

B

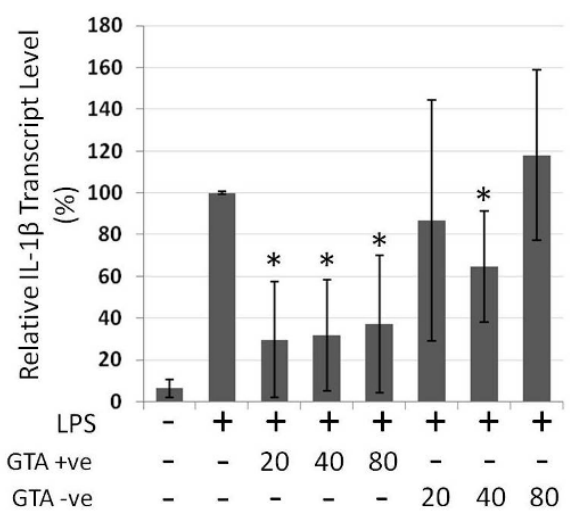

C

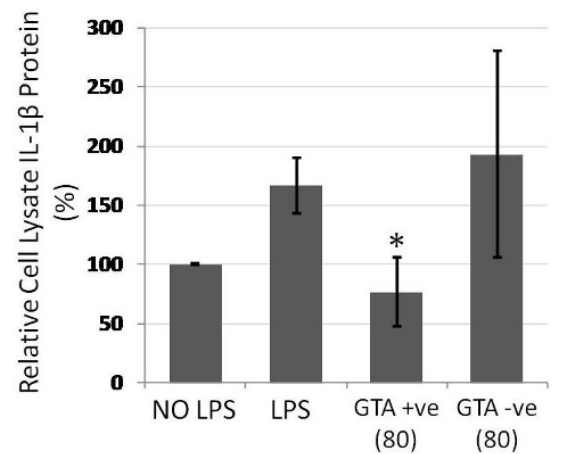

Figure 8 COX2 and IL-1 $\beta$ response in RAW264.7 cells treated with GTA+ve and GTA-ve extracts. RAW264.7 cells were pretreated for 4 hours with GTA+ve or GTA-ve extracts followed by the addition of LPS (1 $\mathrm{ug} / \mathrm{ml})$ for 20 hours. (A) COX2 and (B) IL-1 $1 \beta$ mRNA levels were determined by real-time rtPCR. (C) IL-1 $1 \beta$ levels following $80 \mathrm{ug} / \mathrm{ml}$ treatment in cell lysates as determined by ELISA. Asterisks indicate $p<0.05$ relative to LPS treatment alone. Data are expressed as the average of three duplicate experiments \pm 1S.D.

absent from several types of plant-based products such as grains and seed oils, as well as human tissues including colonic tumors and normal colon epithelium (unpublished observations). This human exclusivity has lead us to speculate that the gut microbiota, in combination with currently unknown dietary precursors, may be involved in their catabolism. The results shown here represent the first report of GTA biological activity, which revealed that cells treated with GTA+ve extracts had reduced proliferative capacity coinciding with PARP fragmentation, significantly down-regulated $N F \kappa B$ expression, increased $\mathrm{I} \kappa \mathrm{B} \alpha$ levels, and numerous downregulated inflammatory markers including nitric oxide, NOS2, IL-1 $\beta$, TNF $\alpha$ and COX2. Given the critical role of $\mathrm{NF} \kappa \mathrm{B}$ in regulating both apoptosis and inflammation and its association with aging, our data suggests that the protective effects of GTAs are mediated, at least in part, through NF $\kappa$ B signalling. A reduction of GTAs over time could therefore be involved in compromising one's ability to protect against chronic inflammation and possibly cancer.

\section{GTAs, fatty acids, and proliferation}

Our observation that GTA+ve extracts dose-dependently reduce cell proliferation, accompanied by the appearance of multiple PARP cleavage products with different molecular weights in SW620 cells but only the $24 \mathrm{kDa}$ fragment in MCF-7 cells, suggests a complex cell-specific interplay between different proteases. Although it has been reported that caspase- 3 activation can result in the 89 and $24 \mathrm{kDa}$ fragments and that cathepsin-b and granzyme-b can produce fragments of 50 and $64 \mathrm{kDa}$, respectively [23], further work will be required to investigate GTA-specific protease activation. Our evidence of apoptosis upon treatment with GTAs is consistent with numerous other reports showing pro-apoptotic effects mediated through polyunsaturated long chain fatty acids (PUFAs). For example, docosahexanaeoic acid (DHA) has been shown to promote apoptosis through numerous pathways including cytochrome-c mediated caspase activation $[24,25]$, inhibition of the regulatory subunit of PI3-kinase, and reduction of PTEN phosphorylation [24,26]. Others have shown that DHA and the PUFA punicic acid ultimately exert their intrinsic effects through dissipation of the mitochondrial membrane potential $[27,28]$, and that DHA and butyrate can promote apoptosis by altering mitochondrial $\mathrm{Ca}^{2+}$ levels [29]. Treatment of various cell lines, for example LAPC-4 prostate cancerderived cells, with PUFAs, has been shown to reduce proliferation and induce apoptosis [30]. There are also studies demonstrating the inhibitory effects of omega-3 PUFAs on growth and angiogenesis of chemically induced as well as transplanted tumor model systems [31-33]. The observation of reduced cell growth in the presence of GTA+ve extract is therefore consistent with a large body of literature showing similar effects with exposure to long-chain PUFAs (see [34] for review). 
In addition to its anti-proliferative effect, GTA+ve extract also protected against the LPS-mediated induction of several pro-inflammatory proteins including TNF $\alpha$, IL- $1 \beta$, NOS 2 and COX2, and inhibited the production of nitric oxide. Central to these two effects (reduced proliferation and inflammation) was the concomitant inhibition of NF $\kappa \mathrm{B}$ upon GTA+ve treatment in SW620 colonic epithelial cells, which correlated precisely with increased levels of the inhibitory protein $\mathrm{I} \kappa \mathrm{B} \alpha$, likely due to stabilization stemming from compromised ubiquitin-dependent proteosomal targeting [35]. The inhibition of $\mathrm{NF} \kappa \mathrm{B}$ is relevant to both apoptotic processes and inflammation, as discussed further below.

\section{$\mathrm{NF} \kappa \mathrm{B}$ and cell proliferation}

$\mathrm{NF} \kappa \mathrm{B}$, a transcription factor represented by a series of subunits harbouring discrete DNA binding and transactivational functionality, is implicated in both intrinsic and extrinsic apoptotic pathways (see [36] for review) and has been shown to prevent apoptosis as well as promote transformation in epithelial-derived cancers [37]. Mechanistically, in the absence of $\mathrm{NF} \kappa \mathrm{B}$ signalling, inhibitor-of-apoptosis proteins (IAPs) fail to suppress assembly of the death-inducing complex II, which allows for the TRADD-mediated activation of caspase- 8 and subsequent apoptosis [36,38]. Furthermore, IAPs can directly promote the ubiquitin-mediated degradation of the NF $\kappa \mathrm{B}$-inducing serine/threonine kinase (NIK), ultimately resulting in $\mathrm{NF} \kappa \mathrm{B}$ activation [39]. Although a detailed discussion on this topic is out of scope, it is well established that activated $\mathrm{NF} \kappa \mathrm{B}$ is associated with an anti-apoptotic pro-survival advantage which is relevant given our data showing that GTA+ve extracts reduced $\mathrm{NF} \kappa \mathrm{B}$ expression. These observations are consistent with the reported biological activity of the resolvins and protectins, which have been shown to exert both pro-apoptotic effects [40] and the resolution of inflammation by attenuating cytokine levels in an $\mathrm{NF} \kappa \mathrm{B}$-dependent manner [41]. One limitation of our study was that we were unable to determine $\mathrm{NF} \kappa \mathrm{B}$ levels in RAW264.7 cells, which will require further investigation upon the generation of sufficient quantities of either enriched extract, or more preferably, purified synthetic GTAs. However, the dramatic reduction of $\mathrm{NF} \kappa \mathrm{B}$ upon GTA treatment in colon tumor cells is highly relevant given the reduced levels of circulating GTAs in CRC patients $[17,18]$ and the well-established inflammatory component of this disease [42].

\section{$\mathrm{NF} \kappa \mathrm{B}$ and inflammation}

Besides its anti-apoptotic role, $\mathrm{NF} \kappa \mathrm{B}$ represents a key link between inflammation and cancer (see [43] for review), and in particular, is considered a master regulator of intestinal immunological function and activator of factors involved in driving intestinal inflammation [44-46]. NF $\kappa \mathrm{B}$ activation has been observed in numerous GI-related conditions including inflammatory bowel disease [47], Crohn's disease [48], ulcerative colitis [35], inflamed intestinal mucosa [49] as well as CRC [50-53]. It has been shown that the $\mathrm{NF} \kappa \mathrm{B}$ transcriptional activity in gastric mucosa is induced during aging [53], that positive $\mathrm{NF} \kappa \mathrm{B}$ expression as assessed through immunohistochemistry is observed in $73.5 \%$ of human CRC tumors independent of age [50], and that levels of $\mathrm{NF} \kappa \mathrm{B}, \mathrm{IKK} \alpha$ and COX2 in tumor epithelial cells from CRC patients are significantly higher than adjacent normal tissue [52].

Also relevant to $\mathrm{NF} \kappa \mathrm{B}$ activation and intestinal inflammation is the reported differential regulation of Toll-like receptors (TLRs) by fatty acids with differing saturation states [54-56]. TLRs are single membrane-spanning proteins involved in the recognition of microbial-derived molecules harbouring pathogen-associated molecular patterns (PAMPs) and activation of various immune cell responses [57]. Upon activation, TLRs activate NF $\kappa \mathrm{B}$ though a complex signalling network culminating with the activation of IKK $\alpha$, followed by ubiquitination and subsequent degradation of $\mathrm{I} \kappa \mathrm{B} \alpha$ and translocation of the P65 Rel A domain to the nucleus where it binds to and activates the expression of numerous pro-inflammatory genes [44]. Specifically, TLR4 has been shown to confer responsiveness to a number of lipids including lipid $\mathrm{A}$, the primary biologically active component of LPS, and that in contrast to saturated fatty acids similar to those found in lipid A, unsaturated fatty acids inhibit NF $\kappa \mathrm{B}$ activity through inhibition of TLR4 or other TLR-associated molecules $[55,56]$. Therefore, it is possible that the anti-inflammatory effects associated with GTAs are being exerted through inhibition of TLRs upstream of $\mathrm{NF} \kappa \mathrm{B}$. Further work to investigate this hypothesis is warranted.

\section{$\mathrm{NF} \kappa \mathrm{B}$, aging and gut microbiota}

A final point concerning NF $\kappa \mathrm{B}$ and GTA metabolism is that both have age-related implications. We previously showed that in the general population, there is an inverse association between the circulating levels of GTA-446 and age, and that the rate of decline correlated precisely with the increase in CRC incidence with age [18]. As for $\mathrm{NF} \kappa \mathrm{B}$, there is substantial literature regarding its various age-related facets [53,58-63]. For example, it has been shown that $\mathrm{NF} \kappa \mathrm{B}$ protein levels, as well as several NF $\kappa \mathrm{B}$-targeted pro-inflammatory cytokines, are elevated in endothelial cells of old versus young subjects, which were also accompanied by decreased $\mathrm{I} \kappa \mathrm{B} \alpha$ levels in the older group [60]. Microarray analysis further showed that the NF $\kappa \mathrm{B}$ cis element is the motif most strongly associated with aging [64] and 
that blockade of $\mathrm{NF} \kappa \mathrm{B}$ in the epidermis of chronologically aged mice resulted in the reversion of both tissue and gene expression characteristics to those of young mice [59]. These and numerous other reports clearly associate increased $\mathrm{NF} \kappa \mathrm{B}$ activity with multiple aspects of aging including immunosenescence, antigenic stress, innate immunity, tissue atrophy, inflammation, cellular danger responses, apoptosis, DNA damage, oxidative stress and caloric restriction (see [62] for review). Left unchecked, therefore, $\mathrm{NF} \kappa \mathrm{B}$ activation is a probable driving force for many of these critical aging-related processes.

Given the selectiveness of GTAs in human blood and their novel hydroxylated and unsaturated fatty acid structures, the possibility that human-specific gut microbial processes may be involved in the metabolism of GTAs from dietary sources cannot be excluded. It is also well known that the intestinal microbiome composition changes with age due to a number of contributing factors including reduced mucosal secretion, decreased nutritional status, changes in luminal $\mathrm{pH}$ and increased drug and antibiotic use [65-68]. There is also evidence that the gut microbiota is intricately linked to obesity and metabolic syndrome, and can perpetuate insulinresistance and chronic inflammation [69-71], all of which have been previously implicated with colon cancer $[42,72-75]$. Lastly, it is intriguing to consider that the modulation of gut microbial composition through the consumption of probiotics and/or fermented milk products has been shown to reduce inflammation and protect against cancer [76-78]. Therefore, investigating the possible interaction between various gut microorganisms and dietary precursors with respect to GTA metabolism is highly justified.

In summary, our findings collectively suggest a mechanism whereby the age-related decline in GTAs in a subset of the general population results in an impaired ability to control chronic inflammation, which over time may lead to oncogenic cellular changes. The measurement of GTAs may therefore represent an opportunity for the early identification of subjects with elevated inflammatory status and subsequent risk of CRC.

\section{List of abbreviations}

CRC: colorectal cancer; GTA: gastrointestinal tract carboxylic acid; PARP: poly (ADP)-ribose polymerase; ADP: adenosine diphosphate; nuclear factor kappa B; NOS2: nitric oxide synthase 2; IL-1B: interleukin 1 beta; TNFa: tumor necrosis factor alpha; COX2: cyclooxygenase 2; AA: arachidonic acid; DHA: docosehexaenoic acid; EPA: eicosapentanoic acid; TIC: total ion current; TOF: time-of-flight; PUFAs: polyunsaturated fatty acids; IAPs: inhibitor of apoptosis proteins; NIK: NFKB inducible kinase; TLR: Toll-like receptor; PAMP: pathogenassociated molecular pattern; IKKa: IkappaB kinase alpha.

\section{Acknowledgements}

We acknowledge Dr. Paul Wood and Alix Hayden for careful review of the manuscript.

\section{Author details}

${ }^{1}$ Phenomenome Discoveries, Inc. Saskatoon, Saskatchewan, Canada.

${ }^{2}$ University of Saskatchewan, Saskatoon, Saskatchewan, Canada.

\section{Authors' contributions}

All authors have read and approved the final manuscript. SR: Lead author, wrote the manuscript, directed and oversaw the research presented. DJ: Purification of serum extracts, chromatography, interpretation of MS data, GFD: western blots, PA: lead development of chromatographic methods, interpretation of MS data, WJ: analysis of samples on HPLC-tandem MS, HM: ELISA experiments, nitrite determinations, cell culture and treatments, and DBG: group leader, interpretation and contribution to writing.

\section{Competing interests}

All authors were employees of Phenomenome Discoveries, Inc. during the course of the work presented in the manuscript. Dayan B. Goodenowe is the president and CEO, and primary shareholder of Phenomenome.

Received: 30 March 2011 Accepted: 17 May 2011

Published: 17 May 2011

\section{References}

1. Schwab JM, Chiang N, Arita M, Serhan CN: Resolvin E1 and protectin D1 activate inflammation-resolution programmes. Nature 2007, 447:869-874.

2. Serhan $\mathrm{CN}$ : Novel chemical mediators in the resolution of inflammation: resolvins and protectins. Anesthesiol Clin 2006, 24:341-364

3. Schwab JM, Serhan CN: Lipoxins and new lipid mediators in the resolution of inflammation. Curr Opin Pharmacol 2006, 6:414-420.

4. Hong S, Lee HJ, Kim SJ, Hahm KB: Connection between inflammation and carcinogenesis in gastrointestinal tract: focus on TGF-beta signaling. World J Gastroenterol 2010, 16:2080-2093.

5. Demaria S, Pikarsky E, Karin M, Coussens LM, Chen YC, El-Omar EM, Trinchieri G, Dubinett SM, Mao JT, Szabo E, Krieg A, Weiner GJ, Fox BA, Coukos G, Wang E, Abraham RT, Carbone M, Lotze MT: Cancer and inflammation: promise for biologic therapy. J Immunother 2010, 33:335-351.

6. Senthil $K$, Aranganathan S, Nalini N: Evidence of oxidative stress in the circulation of ovarian cancer patients. Clin Chim Acta 2004, 339:27-32.

7. Itzkowitz SH, Yio X: Inflammation and cancer IV. Colorectal cancer in inflammatory bowel disease: the role of inflammation. Am J Physiol Gastrointest Liver Physiol 2004, 287:G7-17.

8. Das UN: Folic acid and polyunsaturated fatty acids improve cognitive function and prevent depression, dementia, and Alzheimer's diseasebut how and why? Prostaglandins Leukot Essent Fatty Acids 2008, 78:11-19.

9. Spiteller G: Peroxyl radicals: inductors of neurodegenerative and other inflammatory diseases. Their origin and how they transform cholesterol, phospholipids, plasmalogens, polyunsaturated fatty acids, sugars, and proteins into deleterious products. Free Radic Biol Med 2006, 41:362-387.

10. Mrak RE, Landreth GE: PPARgamma, neuroinflammation, and disease. J Neuroinflammation 2004, 1:5.

11. Sumariwalla PF, Palmer CD, Pickford LB, Feldmann M, Foxwell BM, Brennan FM: Suppression of tumour necrosis factor production from mononuclear cells by a novel synthetic compound, CLX-090717. Rheumatology (Oxford) 2009, 48:32-38.

12. Simmonds RE, Foxwell BM: Signalling, inflammation and arthritis: NFkappaB and its relevance to arthritis and inflammation. Rheumatology (Oxford) 2008, 47:584-590.

13. Jin JQ, Li CQ, He LC: Down-regulatory effect of usnic acid on nuclear factor-kappaB-dependent tumor necrosis factor-alpha and inducible nitric oxide synthase expression in lipopolysaccharide-stimulated macrophages RAW 264.7. Phytother Res 2008, 22:1605-1609.

14. Yun KJ, Koh DJ, Kim SH, Park SJ, Ryu JH, Kim DG, Lee JY, Lee KT: Antiinflammatory effects of sinapic acid through the suppression of inducible nitric oxide synthase, cyclooxygase-2, and proinflammatory cytokines expressions via nuclear factor-kappaB inactivation. J Agric Food Chem 2008, 56:10265-10272.

15. Nakanishi Y, Kamijo R, Takizawa K, Hatori M, Nagumo M: Inhibitors of cyclooxygenase-2 (COX-2) suppressed the proliferation and differentiation of human leukaemia cell lines. Eur J Cancer 2001, 37:1570-1578. 
16. Jobin C, Morteau O, Han DS, Balfour Sartor R: Specific NF-kappaB blockade selectively inhibits tumour necrosis factor-alpha-induced COX-2 but not constitutive COX-1 gene expression in HT-29 cells. Immunology 1998, 95:537-543.

17. Ritchie SA, Ahiahonu PW, Jayasinghe D, Heath D, Liu J, Lu Y, Jin W, Kavianpour A, Yamazaki Y, Khan AM, Hossain M, Su-Myat KK, Wood PL, Krenitsky K, Takemasa I, Miyake M, Sekimoto M, Monden M, Matsubara H, Nomura F, Goodenowe DB: Reduced levels of hydroxylated, polyunsaturated ultra long-chain fatty acids in the serum of colorectal cancer patients: implications for early screening and detection. BMC Med 2010, 8:13.

18. Ritchie SA, Heath D, Yamazaki Y, Grimmalt B, Kavianpour A, Krenitsky K, Elshoni H, Takemasa I, Miyake M, Sekimoto M, Monden M, Tomonaga T, Matsubara H, Sogawa K, Matsushita K, Nomura F, Goodenowe DB: Reduction of novel circulating long-chain fatty acids in colorectal cancer patients is independent of tumor burden and correlates with age. BMC Gastroenterol 2010, 10:140.

19. Davies GF, Roesler WJ, Juurlink BH, Harkness TA: Troglitazone overcomes doxorubicin-resistance in resistant K562 leukemia cells. Leuk Lymphoma 2005, 46:1199-1206.

20. Serhan CN: Controlling the resolution of acute inflammation: a new genus of dual anti-inflammatory and proresolving mediators. J Periodontol 2008, 79:1520-1526.

21. Seki H, Tani Y, Arita M: Omega-3 PUFA derived anti-inflammatory lipid mediator resolvin E1. Prostaglandins Other Lipid Mediat 2009, 89:126-130.

22. O'Connor PM, Lapointe TK, Beck PL, Buret AG: Mechanisms by which inflammation may increase intestinal cancer risk in inflammatory bowel disease. Inflamm Bowel Dis 2010, 16:1411-1420.

23. Chaitanya GV, Babu PP: Differential PARP cleavage: an indication of heterogeneous forms of cell death and involvement of multiple proteases in the infarct of focal cerebral ischemia in rat. Cell $\mathrm{Mol}$ Neurobiol 2009, 29:563-573.

24. Toit-Kohn JL, Louw L, Engelbrecht AM: Docosahexaenoic acid induces apoptosis in colorectal carcinoma cells by modulating the PI3 kinase and p38 MAPK pathways. J Nutr Biochem 2009, 20:106-114.

25. Narayanan BA, Narayanan NK, Reddy BS: Docosahexaenoic acid regulated genes and transcription factors inducing apoptosis in human colon cancer cells. Int J Oncol 2001, 19:1255-1262.

26. Engelbrecht AM, Toit-Kohn JL, Ellis B, Thomas M, Nell T, Smith R: Differential induction of apoptosis and inhibition of the PI3-kinase pathway by saturated, monounsaturated and polyunsaturated fatty acids in a colon cancer cell model. Apoptosis 2008, 13:1368-1377

27. Grossmann ME, Mizuno NK, Schuster T, Cleary MP: Punicic acid is an omega-5 fatty acid capable of inhibiting breast cancer proliferation. Int $J$ Oncol 2010, 36:421-426.

28. Chapkin RS, Seo J, McMurray DN, Lupton JR: Mechanisms by which docosahexaenoic acid and related fatty acids reduce colon cancer risk and inflammatory disorders of the intestine. Chem Phys Lipids 2008, 153:14-23.

29. Kolar SS, Barhoumi R, Lupton JR, Chapkin RS: Docosahexaenoic acid and butyrate synergistically induce colonocyte apoptosis by enhancing mitochondrial Ca2+ accumulation. Cancer Res 2007, 67:5561-5568.

30. Kobayashi N, Barnard RJ, Henning SM, Elashoff D, Reddy ST, Cohen P, Leung P, Hong-Gonzalez J, Freedland SJ, Said J, Gui D, Seeram NP, Popoviciu LM, Bagga D, Heber D, Glaspy JA, Aronson WJ: Effect of altering dietary omega-6/omega-3 fatty acid ratios on prostate cancer membrane composition, cyclooxygenase-2, and prostaglandin E2. Clin Cancer Res 2006, 12:4662-4670.

31. Rose DP, Connolly JM: Antiangiogenicity of docosahexaenoic acid and its role in the suppression of breast cancer cell growth in nude mice. Int J Oncol 1999, 15:1011-1015.

32. Reddy BS, Maruyama H: Effect of dietary fish oil on azoxymethaneinduced colon carcinogenesis in male F344 rats. Cancer Res 1986, 46:3367-3370.

33. Reddy BS, Burill C, Rigotty J: Effect of diets high in omega-3 and omega-6 fatty acids on initiation and postinitiation stages of colon carcinogenesis. Cancer Res 1991, 51:487-491.

34. Wendel M, Heller AR: Anticancer actions of omega-3 fatty acids-current state and future perspectives. Anticancer Agents Med Chem 2009, 9:457-470
35. Visekruna A, Joeris T, Seidel D, Kroesen A, Loddenkemper C, Zeitz M, Kaufmann SH, Schmidt-Ullrich R, Steinhoff U: Proteasome-mediated degradation of IkappaBalpha and processing of p105 in Crohn disease and ulcerative colitis. J Clin Invest 2006, 116:3195-3203.

36. Gyrd-Hansen M, Meier P: IAPs: from caspase inhibitors to modulators of NF-kappaB, inflammation and cancer. Nat Rev Cancer 2010, 10:561-574.

37. Greten FR, Eckmann L, Greten TF, Park JM, Li ZW, Egan LJ, Kagnoff MF, Karin M: IKKbeta links inflammation and tumorigenesis in a mouse model of colitis-associated cancer. Cell 2004, 118:285-296.

38. Varfolomeev E, Vucic D: (Un)expected roles of C-IAPs in apoptotic and NFkappaB signaling pathways. Cell Cycle 2008, 7:1511-1521.

39. Varfolomeev E, Blankenship JW, Wayson SM, Fedorova AV, Kayagaki N, Garg P, Zobel K, Dynek JN, Elliott LO, Wallweber HJ, Flygare JA, Fairbrother WJ, Deshayes K, Dixit VM, Vucic D: IAP antagonists induce autoubiquitination of C-IAPs, NF-kappaB activation, and TNFalphadependent apoptosis. Cell 2007, 131:669-681.

40. Vassiliou EK, Kesler OM, Tadros JH, Ganea D: Bone marrow-derived dendritic cells generated in the presence of resolvin E1 induce apoptosis of activated CD4+ T cells. J Immunol 2008, 181:4534-4544.

41. Arita M, Bianchini F, Aliberti J, Sher A, Chiang N, Hong S, Yang R, Petasis NA, Serhan CN: Stereochemical assignment, antiinflammatory properties, and receptor for the omega-3 lipid mediator resolvin E1. $J$ Exp Med 2005, 201:713-722.

42. Harpaz N, Polydorides AD: Colorectal dysplasia in chronic inflammatory bowel disease: pathology, clinical implications, and pathogenesis. Arch Pathol Lab Med 2010, 134:876-895.

43. Karin M: NF-kappaB as a critical link between inflammation and cancer. Cold Spring Harb Perspect Biol 2009, 1:a000141.

44. Spehlmann ME, Eckmann L: Nuclear factor-kappa B in intestinal protection and destruction. Curr Opin Gastroenterol 2009, 25:92-99.

45. Karrasch T, Jobin C: NF-kappaB and the intestine: friend or foe? Inflamm Bowel Dis 2008, 14:114-124

46. Gadjeva M, Wang Y, Horwitz BH: NF-kappaB p50 and p65 subunits control intestinal homeostasis. Eur J Immunol 2007, 37:2509-2517.

47. Schreiber S, Nikolaus S, Hampe J: Activation of nuclear factor kappa B inflammatory bowel disease. Gut 1998, 42:477-484.

48. Ellis RD, Goodlad JR, Limb GA, Powell JJ, Thompson RP, Punchard NA: Activation of nuclear factor kappa B in Crohn's disease. Inflamm Res 1998, 47:440-445.

49. Rogler G, Brand K, Vogl D, Page S, Hofmeister R, Andus T, Knuechel R, Baeuerle PA, Scholmerich J, Gross V: Nuclear factor kappaB is activated in macrophages and epithelial cells of inflamed intestinal mucosa. Gastroenterology 1998, 115:357-369.

50. Abdullah M, Sudoyo AW, Pranowo BS, Rini D, Sutrisna B, Rani AA: Expression of NF-kappaB and COX-2 in young versus older patients with sporadic colorectal cancer. Acta Med Indones 2009, 41:70-74.

51. Sun XF, Zhang H: NFKB and NFKBI polymorphisms in relation to susceptibility of tumour and other diseases. Histol Histopathol 2007, 22:1387-1398.

52. Charalambous MP, Lightfoot T, Speirs V, Horgan K, Gooderham NJ: Expression of COX-2, NF-kappaB-p65, NF-kappaB-p50 and IKKalpha in malignant and adjacent normal human colorectal tissue. $\mathrm{Br} J$ Cancer 2009, 101:106-115.

53. Xiao ZQ, Majumdar AP: Induction of transcriptional activity of AP-1 and NF-kappaB in the gastric mucosa during aging. Am J Physiol Gastrointest Liver Physiol 2000, 278:G855-865.

54. Lee JY, Zhao L, Youn HS, Weatherill AR, Tapping R, Feng L, Lee WH, Fitzgerald KA, Hwang DH: Saturated fatty acid activates but polyunsaturated fatty acid inhibits Toll-like receptor 2 dimerized with Toll-like receptor 6 or 1. J Biol Chem 2004, 279:16971-16979.

55. Lee JY, Plakidas A, Lee WH, Heikkinen A, Chanmugam P, Bray G, Hwang DH: Differential modulation of Toll-like receptors by fatty acids: preferential inhibition by $\mathrm{n}-3$ polyunsaturated fatty acids. J Lipid Res 2003, 44:479-486.

56. Lee JY, Sohn KH, Rhee SH, Hwang D: Saturated fatty acids, but not unsaturated fatty acids, induce the expression of cyclooxygenase-2 mediated through Toll-like receptor 4. J Biol Chem 2001, 276:16683-16689.

57. Kirschning CJ, Schumann RR: TLR2: cellular sensor for microbial and endogenous molecular patterns. Curr Top Microbiol Immunol 2002, 270:121-144. 
58. Kriete A, Mayo KL: Atypical pathways of NF-kappaB activation and aging. Exp Gerontol 2009, 44:250-255.

59. Adler AS, Kawahara TL, Segal E, Chang HY: Reversal of aging by NFkappaB blockade. Cell Cycle 2008, 7:556-559.

60. Donato AJ, Black AD, Jablonski KL, Gano LB, Seals DR: Aging is associated with greater nuclear NF kappa B, reduced I kappa B alpha, and increased expression of proinflammatory cytokines in vascular endothelial cells of healthy humans. Aging Cell 2008, 7:805-812.

61. Giardina C, Hubbard AK: Growing old with nuclear factor-kappaB. Cell Stress Chaperones 2002, 7:207-212

62. Salminen A, Huuskonen J, Ojala J, Kauppinen A, Kaarniranta K, Suuronen T: Activation of innate immunity system during aging: NF-kB signaling is the molecular culprit of inflamm-aging. Ageing Res Rev 2008, 7:83-105.

63. Salminen A, Ojala J, Huuskonen J, Kauppinen A, Suuronen T, Kaarniranta K. Interaction of aging-associated signaling cascades: inhibition of NFkappaB signaling by longevity factors FoxOs and SIRT1. Cell Mol Life Sci 2008, 65:1049-1058.

64. Adler AS, Sinha S, Kawahara TL, Zhang JY, Segal E, Chang HY: Motif module map reveals enforcement of aging by continual NF-kappaB activity. Genes Dev 2007, 21:3244-3257.

65. Enck P, Zimmermann K, Rusch K, Schwiertz A, Klosterhalfen S, Frick JS: The effects of ageing on the colonic bacterial microflora in adults. $Z$ Gastroenterol 2009, 47:653-658.

66. He F, Ouwehand AC, Isolauri E, Hosoda M, Benno Y, Salminen S: Differences in composition and mucosal adhesion of bifidobacteria isolated from healthy adults and healthy seniors. Curr Microbiol 2001, 43:351-354.

67. Hopkins MJ, Sharp R, Macfarlane GT: Age and disease related changes in intestinal bacterial populations assessed by cell culture, 16S rRNA abundance, and community cellular fatty acid profiles. Gut 2001, 48:198-205.

68. Saunier K, Dore J: Gastrointestinal tract and the elderly: functional foods, gut microflora and healthy ageing. Dig Liver Dis 2002, 34(Suppl 2):S19-24.

69. Musso G, Gambino R, Cassader M: Obesity, diabetes, and gut microbiota: the hygiene hypothesis expanded? Diabetes Care 2010, 33:2277-2284.

70. Fava F, Lovegrove JA, Gitau R, Jackson KG, Tuohy KM: The gut microbiota and lipid metabolism: implications for human health and coronary heart disease. Curr Med Chem 2006, 13:3005-3021.

71. Petruzzelli M, Moschetta A: Intestinal ecology in the metabolic syndrome. Cell Metab 2010, 11:345-346.

72. Gunter MJ, Leitzmann MF: Obesity and colorectal cancer: epidemiology, mechanisms and candidate genes. J Nutr Biochem 2006, 17:145-156.

73. Ehrmann-Josko A, Sieminska J, Gornicka B, Ziarkiewicz-Wroblewska B, Ziolkowski B, Muszynski J: Impaired glucose metabolism in colorectal cancer. Scand J Gastroenterol 2006, 41:1079-1086.

74. Pais R, Silaghi H, Silaghi AC, Rusu ML, Dumitrascu DL: Metabolic syndrome and risk of subsequent colorectal cancer. World J Gastroenterol 2009, 15:5141-5148.

75. Saydah SH, Platz EA, Rifai N, Pollak MN, Brancati FL, Helzlsouer KJ: Association of markers of insulin and glucose control with subsequent colorectal cancer risk. Cancer Epidemiol Biomarkers Prev 2003, 12:412-418.

76. Kumar M, Kumar A, Nagpal R, Mohania D, Behare P, Verma V, Kumar P, Poddar D, Aggarwal PK, Henry CJ, Jain S, Yadav H: Cancer-preventing attributes of probiotics: an update. Int J Food Sci Nutr 2010, 61:473-496.

77. Pufulete M: Intake of dairy products and risk of colorectal neoplasia. Nutr Res Rev 2008, 21:56-67.

78. Saikali J, Picard C, Freitas M, Holt P: Fermented milks, probiotic cultures, and colon cancer. Nutr Cancer 2004, 49:14-24

doi:10.1186/1756-9966-30-59

Cite this article as: Ritchie et al:: Human serum-derived hydroxy longchain fatty acids exhibit anti-inflammatory and anti-proliferative activity. Journal of Experimental \& Clinical Cancer Research 2011 30:59.

\section{Submit your next manuscript to BioMed Central and take full advantage of:}

- Convenient online submission

- Thorough peer review

- No space constraints or color figure charges

- Immediate publication on acceptance

- Inclusion in PubMed, CAS, Scopus and Google Scholar

- Research which is freely available for redistribution

Submit your manuscript at www.biomedcentral.com/submit
Ciomed Central 